\title{
An Overview on Resource Utilization of Sewage Sludge
}

\author{
Bifan He \\ Chongqing City Management College, Chongqing 401331, China
}

\begin{abstract}
The proper disposal of sewage sludge has been paid much attention. The traditional methods of sludge disposal include sanitary landfill, composting, thermo chemical treatment (including pyrolysis and combustion), and sea disposal. Urban sludge has the dual attributes of pollutants and resources. The resource utilization of sludge is the best way for sludge treatment and disposal. In view of the advantages and disadvantages of the traditional sludge treatment methods, this paper summarizes the research status of several typical resource utilization technologies. This paper expounds the latest research progress of the three aspects of energy regeneration and utilization of sludge, conversion and utilization of building materials and land use. The purpose is to promote the reform and further development of sludge utilization.
\end{abstract}

Keywords-sewage sludge; reclamation; review

\section{INTRODUCTION}

With the rapid economic and social development in developing countries, it's speeding up the process of Urbanization. Many waste water treatment plants were set up in developing countries. The amount of sludge produced by municipal sewage treatment in China is increasing rapidly. According to the Ministry of environmental protection of People's Republic of China pollution emission statement shows, till by the end of 2014, the city sewage treatment plant reached 1797, sewage treatment capacity of 131 million cubic meters per day, an increase of 6 million 110 thousand cubic meters per day. The city sewage treatment plant sewage accumulated 38 billion 270 million cubic meters, an increase of 5.9\%, the city sewage treatment rate reached $90.2 \%$. According to the amount of sewage treatment, the sewage sludge amount is close to 30 million (with the moisture content about $80 \%$ ) tons every year. How to dispose the sewage sludge is a big problem.

Traditionally, the treatment of sewage sludge mainly includes landfill, composting, throwing and incineration. Studies have shown that sludge pollutants have long-term toxicity and biodegradability. If emission, it will become pollution source of contamination through the atmosphere, groundwater, surface water and soil medium into the food chain, causing serious ecological risk, affect human health. At the same time, sewage sludge contains a large number of organic matters, nitrogen, phosphorus and other nutrients. If properly treated, it can be used as good resources. In this paper, the main research progress of sludge resource utilization was reviewed. The purpose is to promote the further development of sludge utilization.

\section{ENERGY UTILIZATION}

\section{A. Pyrolysis Oil}

The thermo-chemical utilization of biomass includes 4 technologies: the most popular combustion and co-firing, and unconventional: pyrolysis and gasification. Low temperature pyrolysis of sewage sludge is a kind of sludge derived fuel, such as better combustion characteristics, which is produced by the partial pyrolysis of sludge organic matter. The pyrolysis method is the most promising method to recover the energy. It can improve the utilization rate of sludge. Low temperature pyrolysis is the most effective method of sludge treatment. The technology of producing oil, carbon and combustible gases by sewage sludge attract the attention of the academic circles.

Scholar JIA Xiang-ru [1] did experiments on the pyrolysis of sludge in dual fluidized bed. The semi coke combustion process was key point of the experiments. The results showed: (i) The composition of pyrolysis oil is complex; (ii) Including benzene and its compounds, olefin, carboxylic acids, polycyclic aromatic hydrocarbons, nitrogen-containing compounds, chlorinated compounds and esters; (iii) The composition of pyrolysis oil showed strong regularity with the increase of pyrolysis temperature; (iv) At low temperature, the ester content is the absolute advantage; (v) When the temperature is relatively high, the composition of pyrolysis oil is even, and the olefin content is the highest. Ji Ai-min ${ }^{[2]}$ used the distillation process to process the sludge pyrolysis oil to obtain a lighter class gasoline component. The chemical composition analysis was carried out by GC-MS, and it was found that the gasoline component was expected to be a substitute fuel for gasoline. The composition analysis of gasoline components in sludge pyrolysis oil products is shown in the following table:

\section{TABLE I. CHARACTERS OF THE RAW MATERIALS ${ }^{[2]}$}

\begin{tabular}{ccccccc}
\hline & \multicolumn{5}{c}{$w / \%$} & $\begin{array}{c}\text { Heating value } \\
Q / \mathrm{MJ}^{-} \mathrm{kg}^{-1}\end{array}$ \\
\cline { 2 - 6 } & $\mathrm{C}$ & $\mathrm{H}$ & $\mathrm{N}$ & $\mathrm{S}$ & 0 & 13.8 \\
Sludge & 39.7 & 5.6 & 3.8 & 1.2 & 49.7 & 25.1 \\
Pyrolysis oil & 57.9 & 8.3 & 4.0 & 1.0 & 29.0 & 31.9 \\
Gasoline-like fraction & 68.0 & 8.6 & 4.9 & 1.1 & 17.5 & \\
\hline
\end{tabular}

As it can be seen from table I, the $\mathrm{C}, \mathrm{H}$ elements and calorific value of raw sludge are lower than that of pyrolysis oil and gasoline. The calorific value of pyrolysis oil is lower than that of gasoline. However, pyrolysis oil is rich in high $\mathrm{C}$, $\mathrm{H}$ elements, which also corresponds to a higher calorific value. It's important to obtain the fuel instead of the petrochemical energy and to control the secondary pollution of sludge to the environment. It is a difficult problem that how to purify the components of pyrolysis gasoline and promote the commercial 
application. How to convert the experimental results of sludge pyrolysis to large-scale production is the direction of further research.

\section{B. Biogas}

By using sludge to produce methane is a useful method to reuse sewage sludge. Under the condition of anaerobic digestion and other suitable conditions, the sludge can produce a mixture of methane. Through anaerobic process of sludge to produce biogas can solve the problem of sludge outlet. Its great significance was to be conducive to save energy and reduce waste water treatment plant operating costs.

Scholar LIU Xiao-ling ${ }^{[3]}$ did researches about anaerobic digestion of sludge: A high solid concentration and anaerobic digestion process was used to study the fermentation process of batch anaerobic digestion of sludge in $5 \mathrm{~L}$ reactor with a total solids (TS) content of $17 \%$. In this case, the feasibility of anaerobic digestion process with high solid concentration for the conversion of sludge to biogas was analyzed. The results came out to be: (i) The daily output and daily $\mathrm{CH} 4$ of sludge in the anaerobic digestion process with high solid concentration showed a continuous fluctuation of wave shape; (ii) The content of methane in biogas is relatively stable; (iii) High solid concentration anaerobic digestion process can significantly improve the efficiency of biogas yield and effective volume of $\mathrm{CH} 4$ yield, and significantly reduce the sludge TS and VS content. Zhao Yun-fei ${ }^{[4]}$ carried out research on the characteristics of gas production of food waste and sludge anaerobic fermentation. The results showed: (i) With the increase of the ratio of the sludge in the mixed substrate, the cumulative biogas production rate increased first and then decreased; (ii) When the proportion of kitchen garbage and sludge is 30/30, the cumulative biogas yield reached the highest value for $612 \mathrm{~mL} / \mathrm{gVS}$. Zhang Li-jun ${ }^{[5]}$ made a comprehensive analysis on the comprehensive utilization of anaerobic digestion of sludge. The research data are from the industrial practice, which can be used as a reference for the economic operation of other sludge anaerobic digestion systems and the choice of comprehensive utilization of Biogas. He point out: (i) Simple use of biogas boiler is not realistic, the demand for heat is limited to the factory, the greater the impact of the season, uneconomical; (ii) Biogas power generation can significantly save running electricity, but the follow-up operation is relatively complex. Sludge is rich in protein, carbohydrates and lipids and other organic ingredients. These organic substances are converted into biogas by anaerobic digestion process. It can not only solve the environmental problems caused by sludge, but also is expected to ease the current increasingly tense energy supply and demand contradiction.

Biomass is one of the major sources of energy that is estimated to contribute between $10 \%$ and $14 \%$ of the world's energy supply. Over the past several years, many societies have established policy targets to increase their production of renewable energy from biomass. Scholar Werle Sebastian evaluated the possibility of the sewage sludge gasification gas use as a fuel ${ }^{[6]}$. The research results showed that Gasification is considered to be the perspective technology because has many advantages in comparison to traditional process of combustion.

\section{Hydrogen}

Hydrogen has abundant resources, high combustion heat, clean and pollution-free, wide application range, has been considered as the ideal energy in twenty-first Century. As a renewable and clean fuel, hydrogen has been widely recognized in the environmental protection industry. The sewage sludge contains a large number of organic matter, it can be used to produce hydrogen.

Liu Chang-qing ${ }^{[7]}$ carried out a batch experiment to study the hydrogen production from acid pretreated sludge by anaerobic fermentation. Miss Liu pointed out: (i) Acid pretreatment can inhibit the consumption of hydrogen bacteria; (ii) The optimal pretreatment condition was $\mathrm{pH}=3.0$ of sludge, and static 24h. (iii) Under the condition of $\mathrm{pH}=3.0$ pretreatment, the maximum cumulative hydrogen production was $14.66 \mathrm{~mL}$ under the condition of initial $\mathrm{pH}=11.0$. Pyrolysis of sewage sludge was conducted in a single-mode microwave reactor and an electric-heated tube furnace, respectively. The effects of particle size, moisture content, pyrolysis temperature, and structure of microwave receptor on the yield and composition of hydrogen-rich gas were studied [8]. Researcher Wang Xiao-lei said: Because of the advantages of selectivity, volume heating, high efficiency and safety, microwave pyrolysis technology has a wide application potential in the field of high temperature pyrolysis of sludge. The effects of pretreatment temperature on hydrogen production characteristics of activated sludge fermentation were investigated by shake flask fermentation ${ }^{[9]}$. The results showed: (i) The aerobic activated sludge of municipal wastewater treatment plant can significantly increase the activity of anaerobic fermentation hydrogen production by $30 \mathrm{~min}$ treatment of not less than $65^{\circ} \mathrm{C}$. The organic matter in the sludge can also be used to produce hydrogen. At present, hydrogen production from sludge is mainly biological fermentation, gasification, pyrolysis and other technologies. It is of great significance to further develop the industrial equipment for hydrogen production from sludge.

\section{Synthetic Fuel}

Sewage sludge contains a large number of organic matter and lignin, they are combustible components. The sludge can be used as the raw material of synthetic fuel by proper pretreatment. Because of the low calorific value of sewage sludge, it need to be blended with auxiliary fuel to manufacture mixed fuel.

Skoglund Nils carried out experiments on fuel design in co-combustion of demolition wood chips and municipal sewage sludge ${ }^{[10]}$. The experimental results indicate: (i) By combusting sludge that is not used directly in agriculture the problematic organic content could be destroyed; (ii) The combustion process also produces an ash that possibly could be used either directly in agriculture or as a raw material for recovering phosphorus and energy could be recovered. Scholar Li Jian ${ }^{[11]}$ studied the physical and chemical properties of sludge mixed with low rank lignite to produce solid fuels. Mr. Li pointed out: (i) With the increase of the temperature, the carbon content increases and the heat value increases; (ii) After upgrading, hydrophobic solid fuel enhancement, heavy water absorption capacity decreased, the degree of coalification 
deepened; (iii) Sludge and lignite after upgrading, the pore structure of solid fuel development, to increase the activity of the combustion or gasification process. Scholar Zhao Pei-tao [12] used the 24t/d test platform, to carry out sludge incorporation of chemical amendments, straw preparing solid fuel experiments. The results showed that the $\mathrm{Fe}^{3+}$ and $\mathrm{Ca}^{2+}$ as conditioner, sludge and straw preparation of solid fuel optimal iron calcium ratio and fuel filter optimal time were 1: 4 to 1: 2 and 6 hours. Sludge fuel is considered as one of the most promising methods in sludge treatment technology, and the research of process and fuel combustion performance has become a hot spot in the field of sludge treatment. Małgorzata did researches on technical and economic optimization of the bio-solid fuels from municipal sewage sludge ${ }^{[13]}$. The analysis involved the production of two types of fuel compositions: sewage sludge with sawdust (PBT fuel) and sewage sludge with meat and bone meal (PBM fuel). The results of the optimization analysis showed that under appropriate conditions, such as prices of components and prices of produced fuels, the production of fuels from sewage sludge can be profitable. How to improve the combustion performance of the synthetic fuel and reduce the secondary pollution of the combustion process of the synthetic fuel has yet to be strengthened.

\section{MANUFACTURE OF BUILDING MATERIALS}

\section{A. Ceramsite}

Sludge ceramsite was first proposed by Nakouzi et al. It took sewage sludge as the main raw material, mixed with appropriate amount of binder and modifier, after mixing, granulation, roasting and cooling process, the sludge ceramsite was made out.

Professor Weng ${ }^{[14]}$ studied the manufacturing technology and performance of sludge ceramsite. Combined with the characteristics of low temperature drying of sludge, the process of sludge drying and ceramic firing was established. Mr. Weng pointed out: (i) The compressive strength increases with the increase of apparent density; (ii) The effect of sintering temperature on the compressive strength and apparent density of sludge ceramsite was significant; (iii) The waste heat of flue gas in the process of sludge ceramsite firing can be used as the heat source of sludge drying; (iv) in this case, the microstructure of ceramic structure under different firing temperatures is shown in the following figure 1.

As it can be seen in Fig I, the crystallinity, porosity and sintering temperature of ceramsite products have a positive correlation. Professor Weng pointed out the significance of the comprehensive utilization of energy recovery in the process of sintering ceramsite, which laid a practical foundation for the application of the technology of sludge ceramsite. Lin Zi-zen [15] did researches on the influence of sintering temperature on the preparation of sludge ceramsite.

$$
\text { The research point out: (i) } \frac{\mathrm{Al}_{2} \mathrm{O}_{3}+\mathrm{SiO}_{2}}{\mathrm{Fe}_{2} \mathrm{O}_{3}+\mathrm{CaO}+\mathrm{MgO}+\mathrm{Na}_{2} \mathrm{O}+\mathrm{K}_{2} \mathrm{O}}
$$
can be used to characterize the firing temperature of the mixture; (ii) The main crystalline phase of sludge ceramsite is quartz ceramic and kyanite. Scholar Su Zi-yi ${ }^{[16]}$ took sludge as the main raw materials, fly ash and bentonite as auxiliary materials, acquired light and high specific surface area ceramsite by orthogonal experiment. It is an efficient way to utilize the sludge to produce ceramsite.

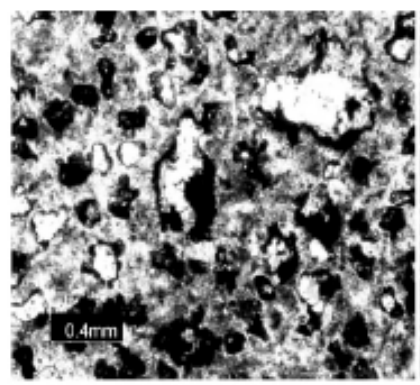

(a) $-900{ }^{\circ} \mathrm{C}$

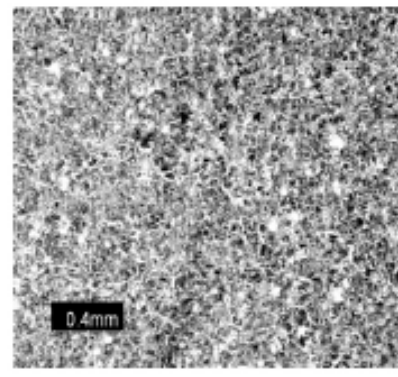

(c) $-1075^{\circ} \mathrm{C}$

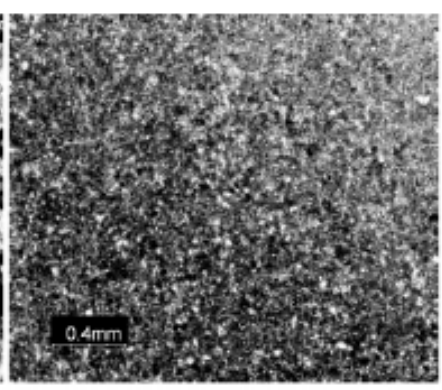

(b) $-1000^{\circ} \mathrm{C}$

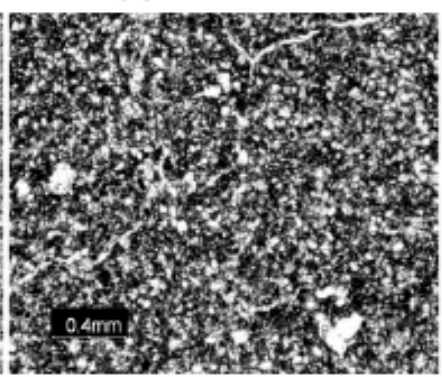

(d) $-1200^{\circ} \mathrm{C}$

\section{FIGURE I. HAYDITE IN DIFFERENT TEMPERATURES} OBSERVED UNDER MICROSCOPE

Ceramsite with high strength, good insulation and sound insulation, fire resistance, chemical corrosion, etc., are used in construction, metallurgy and other industries. In addition, because of its large specific surface area, high porosity, high adsorption capacity and other advantages, ceramsite is often used as a sewage treatment filter media. The energy consumption of ceramsite is high, how to optimize the sintering process, reduce energy consumption and secondary pollution is the next research focus.

\section{B. Brick}

The sewage sludge contains components of building materials, so it can be used to produce ordinary bricks. In order to use solid waste to develop new building materials effectively, based on orthogonal experiment principle, building rubbish, sludge, fly ash and gypsum were used as main raw materials to prepare the no-roasting bricks ${ }^{[17]}$. The brick belongs to the environmental protection, energy-saving building materials. For the construction of environment-friendly society is of great significance. An experimental study was carried out on the preparation of lightweight sintered brick by using municipal sewage sludge and coal gangue as raw materials ${ }^{[18]}$. Miss Pei said that when coal gangue: sludge $=60$ : 40 , the rice husk was added as the pore forming agent: (i) if the content of rice husk is $6 \%$, the compressive strength of the brick is $10.27 \mathrm{MPa}$, which can meet the national standard of the compressive strength of the load-bearing wall material; (ii) When the content of rice husk is $10 \%$, the compressive strength is $4.44 \mathrm{MPa}$, which can meet the national standard of the compressive strength of non-bearing wall material. Fired brick and no-roasting brick are environmentally friendly building materials, each with 
advantages and disadvantages, it is essential to use the sludge for brick building materials.

\section{Synthetic cement}

The ash and chemical characteristics of the sewage sludge were close to clay minerals. Therefore, the sludge can replace some clay raw materials to participate in the production of cement clinker. A study on the production of ecological cement from the activated sludge of municipal wastewater treatment plant was carried out ${ }^{[19]}$. In this case, Mr. Lin found out: It is necessary to strictly control the amount of sludge mixed with sewage sludge by using the existing production line of cement plant to be less than $10.0 \%$. Scholar Zhang used the lime dry sludge as a partial replacement for cement raw materials to produce cement, the admixture of dry sludge could reach $15 \%{ }^{[20]}$. However, how to ensure the safety of the sludge mixed with the clinker products in the cement kiln is also a concern. The engineering application of the sludge directly into the calcined cement has not been reported.

\section{Degradable Plastics}

Biodegradable plastic refers to the degradation in soil microorganism and enzyme under the action of the plastic. In addition to the physical and mechanical properties of traditional plastics, PHA also has the characteristics of complete biodegradability, biocompatibility, piezoelectricity and so on. It is an ideal material for replacing synthetic plastics. In recent years, some scholars have found that the use of activated sludge can not only synthesize PHAs, but also can greatly reduce the cost, so it has been widely concerned.

Scholars have carried out the research on the production of degradable plastics by using residual activated sludge ${ }^{[21]}$. Mr. Zhang pointed out: (i) it is feasible to produce degradable plastics by using residual activated sludge; (ii) In this case, we propose a new method for the synthesis of degradable plastics with the combination of high concentration organic wastewater and domestic sewage. Bacterial fermentation is the main method for the synthesis of biodegradable plastics. However, its production costs are relatively expensive. Activated sludge process will be a promising method for the synthesis of degradable plastics. The feasibility study on the synthesis of biodegradable plastics by activated sludge process was carried out ${ }^{[22]}$. Scholar YU made a conclusion as: (i) The production of PHAS by activated sludge has the characteristics of environmental economy, which is consistent with the concept of sustainable development; (ii) Most of the researches on the utilization of activated sludge in the synthesis of PHA are still in the experimental stage; (iii) How to reduce production cost is the key to realize large-scale engineering production. It is urgent to carry out the pilot study on the synthesis of PHAS from activated sludge.

\section{LAND USE}

\section{A. Compost}

Sludge compost is a good soil conditioner. When compost is used in farmland, it can increase organic matter, improve soil structure, reduce fertilizer use, and can reduce the potential erosion of the soil. As a large number of organic matter, a variety of nutrients, trace elements, sludge compost as a renewable resource has attracted people's attention.
Professor Xu Xin-yang carried out the experimental study on sludge composting of municipal wastewater treatment plant [23]. He pointed out: Static high temperature aerobic composting control temperature of 55 to $60{ }^{\circ} \mathrm{C}$, and maintained above 3days, composting products could meet the requirements of national health standards. An experimental study on the treatment of dewatered sludge with microbial fuel cell anaerobic composting system was carried out ${ }^{[24]}$. In this case, researcher Yu Hang found out: Microbial fuel cells can be used for the treatment of excess sludge, which can accelerate the anaerobic degradation of organic compounds in the sludge. An experimental study on co-composting of municipal sewage sludge and penicillin fermentation dregs was carried out ${ }^{[25]}$. The results showed that the sludge mixed with penicillin bacteria can effectively realize the harmless treatment of penicillin slag. Sludge composting is an important way of sludge utilization. Scholars did researches on the release of heavy metals during long-term land application of sewage sludge compost: Percolation leaching tests with repeated additions of compost ${ }^{[26]}$. In this case, leaching assessment is extended to evaluate the potential leaching of heavy metals during repetitive application of composted sewage sludge to soils. Results showed that repetitive additions of compost to soil significantly increased the content of organic matter, which favored the formation of reducing condition due to improved microbial activities and oxygen consumption.

However, study on the safety of food chain sludge compost products should be further strengthened. On the other hand, sludge compost shortcomings include the time-consuming, odor pollution, easily affected by the weather, market sales, raw material dispersion and so on.

\section{B. Landfill cover material}

The modified sludge was used as landfill cover material to make full use of the closed characteristics of landfill to prevent the pollution of sludge to the environment. At the same time, sludge is also used as a resource. Therefore, it is of great significance to study the modification of sludge as landfill cover material. Professor HE carried out an experimental study on sludge as landfill cover material ${ }^{[27]}$. The research point out: (i) (mass percentage) sludge: Lime: cement: sludge: fly ash =100: 15: 5: 70: 10, after 3 days of natural conservation, the strength and permeability of the modified sludge can basically meet the requirements of the landfill cover material; (ii) The drying shrinkage of modified sludge is strong and the expansion is weak, so it is necessary to pay attention to prevent the adverse effects of dry cracks on the permeability of the modified sludge. A study of the waste landfill final cover material using digested sludge was carried out ${ }^{[28]}$. In this case, professor HUANG pointed out: (i) when the sludge with $60 \%$ moisture content was mixed with slag (mass fraction) of about 2 to 1 , the modified digested sludge accorded with the requirements of the landfill cover material. (ii) slag can be used as the modified material.

\section{CONCLUSION}

With the development of society, China's sewage treatment rate is increasing, the sludge production is increasing. Sludge is rich in nutrients and available inorganic components. We 
should make use of resources as much as possible under the premise of taking into account the environmental benefits, social benefits and economic benefits.

The utilization of sludge will be the development direction of sludge disposal in line with China's national conditions. At present, China's industrial wastewater and domestic sewage is still mixed. This leads to a high content of heavy metals in sludge, and high moisture content of sludge. At the institutional level, China is still lack of relevant standards and regulations of sludge utilization. There are many ways of sludge utilization. How to choose a targeted, economic and technical feasibility of sludge recycling technology is the primary problem. The research points out that only considering the technology characteristics of the sewage treatment area, sludge properties and the needs of the industry, to carry out scientific and reasonable conditions, the sludge resources, avoid blind investment caused environmental and economic losses.

\section{ACKNOWLEDGMENT}

At the point of finishing this paper, I'd like to express my sincere thanks to all those who have lent me hands in the course of my writing this paper. First of all, I would like to thank the Chongqing Municipal Education Commission for the backbone of the teachers' funding scheme. Secondly, I'd like to express my gratitude to my assistants who offered me references and information on time. Last but not the least; I'd like to thank those leaders and working staff. Without their help, it would be much harder for me to finish this paper.

\section{REFERENCES}

[1] JIA Xiang-ru, JIN Bao-sheng, LI Rui. Fast Pyrolysis of Sewage Sludge in a Fluidized Bed for Oil from Sludge [J]. Journal of Combustion Science and Technology,2009,(06):528-534.

[2] JI Ai-min, ZHANG Shu-ting, XU Hui, etal. Composition and fuel characters of gasoline-like fraction in the pyrolysis oil of sludge [J]. Journal of Fuel Chemistry and Technology,2011,(03):194-197.

[3] LIU Xiao-ling, LI Shi-zhong, LIU Jian-shuang, etal. Evaluation of high-solids anaerobic digestion process for converting excess sludge to biogas [J]. Journal of Environmental Sciences,2011,(05):955-963.

[4] ZHAO Yunfei, LIU Xiaoling, LI Shizhong, etal. Characteristics of high-solids anaerobic co-fermentation for converting food waste and excess sludge to biogas[J].Transactions of the CSAE, 2011,27(10):255 -260 .

[5] ZHANG Lijun, XIE Jirong, MA Wenjin, etal. Cost optimization of anaerobic digestion of Biogas [J]. Water \& Wastewater Engineering,2014,(S1):145-148.

[6] Werle S, Dudziak M. Evaluation of the possibility of the sewage sludge gasification gas use as a fuel[J]. Ecological Chemistry \& Engineering S, 2016, 23(2).

[7] Liu CQ, Zhao YC, Zhang JS, etal. Bio-hydrogen production from acid pretreated municipal sludge [J]. ActaScientiaeCircumstantiae, 2008,28(10):2006-2011

[8] WANG XL, DENG WY, YU WC,etal. Hydrogen-rich gas formation characteristics during microwave-induced high temperature pyrolysis of sewage sludge [J]. Journal of Fuel Chemistry and Technology, 2013,(02):243-251.

[9] CHANG Sheng, LI JIanzheng, WANG Shujing,etal. Effects of pretreatment temperature on hydrogen production from activated sludge fermentation [J]. ACTA ENERGIAE SOLARIS SINICA,2011,(03):395-401. (inChinese)

[10] Skoglund N, Bäfver L, Fahlström J, et al. Fuel design in co-combustion of demolition wood chips and municipal sewage sludge[J]. Fuel Processing Technology, 2016, 141(1):196-201.
[11] LI Jian, LIU Meng, DUAN Yufeng, etal. Physicochemical analysis on hydrothermal upgrading of sewage sludge with lignite for solid fuel[J]. Journal of Zhejiang University (Engineering Science),2016,(02):327-332+340. (inChinese)

[12] ZHAO PT, GE SF, ZHANG CF, etal. Pilot scale process and combustion characteristics of sludge and straw biomass solid fuel [J]. Transactions of the Chinese Society of Agricultural Engineering,2012,(09):165-170. (inChinese)

[13] Wzorek M. Production of biosolid fuels from municipal sewage sludge: technical and economic optimisation.[J]. Waste Management \& Research the Journal of the International Solid Wastes \& Public Cleansing Association Iswa, 2015, 33(8):704.

[14] WENG HX, ZHANG JJ, CAO YS,etal. Characteristics and sintering technology of haydite made of sewage sludge[J]. Journal of Zhejiang University (Engineering Science),2011,(10):1877-1883. (inChinese)

[15] LIN ZZ, HUANG Y, XIE WL. Study on the influence of sintering temperature on the preparation of sludge ceramsite [J]. Journal of Functional Materials,2013,(S1):89-93. (inChinese)

[16] SuZiyi, YuJiang, WangCi, etal. Preparation of lightweight and high specific surface area ceramsites with sewage sludge[J]. Journal of Shen zhen University Science and Engineering , 2014 , 31(4):374-378. (inChinese)

[17] XU ZIfang, ZHANG Mingxu, LI Jinhua. Experimental Study on No-roasting Bricks Made from Sludge and Building Rubbish [J]. Non-MetallicMines,2011,(05):11-14.

[18] PEI Hui-fang, ZHANG Chang-sen, CHEN Jing-hua. Preparation and Property of Light Sintered Brick with Sewage Sludge Coal Gangue and Rice Husk [J]. BULLETIN OF THE CHINESE CERAMIC SOCIETY,2015,(02):358-363.

[19] LIN Yiming, ZHOU Shaoqi, CHEN An'an. Waste water treatment plant activated sludge for production of eco-cement [J]. CIESC Journal,2011,(04):1117-1123.

[20] ZHANG K, XING Y, HONG C, etal. Effect of preparation of cement with lime on the properties of cement[J]. Chinese Journal of Engineering,2013,(12):1628-1635.

[21] ZHANG B, ZHANG ZB. Study on Synthesis and process parameters of biological plastics by using activated sludge [J]. Journal of Southwest University for Nationalities(Natural Science Edition),2011,(01):114-118.

[22] YU MX, PAN Y, QIAN YF, etal. Discussion on engineering feasibility of biodegradable plastics synthesized by activated sludge process [J]. Environmental Pollution \& Control,2012,(09):96-101.

[23] XU Xin-yang, CHEN Xi, LIU Qing, etal. Research on the Optimization of Sludge Composting Process for Municipal Waste water Treatment Plant [J]. Journal of Northeastern University(Natural Science),2012,(09):1340-1343+1348.

[24] YU Hang, JIANG Junqiu, ZHAO Qingliang, etal. Treatment of dewater sludge by microbial fuel cell-anaerobic composting system [J]. Journal of Harbin Engineering University,2013,(08):1045-1051.

[25] WEN Qinxue, CHEN Xi, ZHANG Shihua, etal. Experimental study on co-composting of municipal sewage sludge and penicillin fermentation dregs [J]. JOURNAL OF HARBIN INSTITUTE OF TECHNOLOGY,2014,(04):43-49.

[26] Wen F, Delapp R C, Kosson D S, et al. Release of heavy metals during long-term land application of sewage sludge compost: Percolation leaching tests with repeated additions of compost[J]. Chemosphere, 2017, 169:271-280.

[27] HE Jun, LI Feng, LI Yong. Geotechnical Characteristics of Sewage Sludge for Final Cover of Landfill[J]. Chinese Journal of Underground Space and Engineering,2014,(S1):1612-1616.

[28] HUANG Chuan, MA Peidong, WANG Li'ao, etal. Study of the waste landfill final cover material using digested sludge [J]. Environmental Pollution \& Control,2007,(03):197-199+225. 